\title{
Studies on certain quality attributes of meat pickle prepared from spent chicken
}

\author{
Ankur Das, Dilip Ranjan Nath, Mineswar Hazarika and Saurabh Kumar Laskar \\ College of Veterinary Science, \\ Assam Agricultural University, Khanapara, Guwahati - 781 022, Assam, India \\ Corresponding author: Ankur Das, email:drankur0000@yahoo.co.uk \\ Received: 09-07-2012, Accepted: 30-07-2012, Published online: 27-12-2012
}

How to cite this article:

Das A, Nath DR, Hazarika M and Laskar SK (2013) Studies on certain quality attributes of meat pickle prepared from spent chicken, Vet World 6(3): 156-158, doi: 10.5455/vetworld.2013.156-158

\begin{abstract}
Aim: An attempt was made to develop a desirable meat pickle from the less tender and low demand spent chicken meat with the prime objective of its better marketability and wider acceptability amongst the non-vegetarian masses.

Materials and Methods: Lean of culled spent meat was marinated for overnight and then pressure cooked and fried with spices and condiments to prepare a shelf stable meat pickle. Proximate composition, $\mathrm{pH}$, TBA Values, Total viable plate count, Counts for yeast and moulds and sensory quality of the pickles were studied as per standard procedure.

Results: The mean per cent moisture, crude protein, ether extract and total ash contents were $61.89 \pm 0.12,17.28 \pm 0.56$, $14.65 \pm 0.16$ and $3.35 \pm 0.17$ respectively. The product $\mathrm{pH}$ and the yeast and mould counts though did not differ significantly amongst the storage periods, yet there were significant differences $(\mathrm{p}<0.01)$ in TBA and total viable plate count amongst the storage periods. Organoleptic studies with score card method recorded a progressive decrease in the mean panel scores along with the increased storage periods.
\end{abstract}

Conclusion: The spent chicken meat pickle was found to be acceptable for consumption up-to 90 days of storage at room temperature.

Keywords: spent chicken, pickle, quality attributes

\section{I ntroduction}

Poultry industry, a cheap source of animal protein has taken a quantum leap in the last three decades evolving from a near backyard practice to a venture of industrial promotion. Along with this development, availability of culled and spent hens has also increased manifold, but the utilization and consumption of meat from these culled birds are markedly less because of poor sensory quality apart from the toughness of meat. Application of suitable and acceptable processing technology leading to the value addition of spent chicken meat would be a suitable remedy to its disposal problem besides enhancing its acceptability as it will suit the taste buds of local consumers. It has been widely recognized that pickling of meat with edible oil, salt, spices, condiments and vinegar not only enhances its acceptability but also provides better storage life even at ambient temperature [1]. These ready-to-eat meat products can be used as side dish to roti, chapatti, paratha, rice etc.

Perishability of meat food products has been regarded as a very serious problem particularly in countries like India where climate is hot and humid and house-hold refrigeration facility is scanty [2]. It is in this context, preparation of a suitable meat pickle from spent chicken meat may be considered as the need of the hour.

\section{Materials and Methods}

Culled spent hens of around 72 weeks of age were procured from the Instructional Poultry Farm, College of Veterinary Science, Assam Agricultural University, Khanapara, Guwahati - 781 022. These birds were slaughtered and dressed in the Department of Livestock Products Technology, College of Veterinary Science, Assam Agricultural University, Khanapara, Guwahati - 781022 following the standard New York Style of slaughtering and dressing. The dressed carcasses were manually deboned as per the method of Staff and Darrow [3] and the lean meat carcass meat was cut into pieces of 0.5 to 1.0 inches in size.

These cut pieces were than mixed with a pinch of salt and immerged in $2.5 \%$ vinegar $(\mathrm{v} / \mathrm{v})$ overnight for marination. After marination, the meat pieces were removed from the vinegar and pressure cooked $(1.2 \mathrm{~kg} /$ $\mathrm{cm}^{2}$ at $120^{\circ} \mathrm{C}$ ) for 10 minutes. On removal, meat pieces were fried in refined vegetable oil $\left(350^{\circ} \mathrm{C}\right)$ till it develops a golden brown colour. After removal of the fried meat pieces, spices mix (Table-1) prepared as per the recipe of Deogade et al. [4] with some modifications were added to the oil and fried thoroughly for 2 minute after removal of the fried meat pieces. The left out broth was added to the spices mix with constant stirring and allowed to boil for 1 minute. The fried meat pieces were then added to the gravy and further cooked 
Table-1. Recipe of spices mixture used in the chicken pickle (as per Deogade et al. [4] with some modifications)

\begin{tabular}{llc}
\hline Sr. No. & Ingredients & $\begin{array}{c}\text { Percent } \\
\text { (on fresh meat weight) }\end{array}$ \\
\hline 1. & Chilli powder & 1.10 \\
2. & Turmeric powder & 0.45 \\
3. & Coriander powder & 0.55 \\
4. & Cumin powder & 0.55 \\
5. & Black pepper powder & 0.12 \\
6. & Cinnamon powder & 0.17 \\
7. & Clove powder & 0.11 \\
8. & Large cardamom powder & 0.17 \\
9. & Common salt & 2.5 \\
10. & Commercial chicken masala (Make: Sona) & 1 \\
11. & Onion & 28.00 \\
12. & Ginger & 4.20 \\
13. & Garlic & 4.30 \\
\hline
\end{tabular}

Table-2. Influence of storage period on $\mathrm{pH}$, TBA value and Microbial counts of spent chicken pickle

\begin{tabular}{|c|c|c|c|c|}
\hline \multirow{2}{*}{ Parameters } & \multicolumn{4}{|c|}{ Storage days } \\
\hline & 0 day & $30^{\text {th }}$ day & $60^{\text {th }}$ day & $90^{\text {th }}$ day \\
\hline $\mathrm{pH}$ & $4.72 \pm 0.12$ & $4.75 \pm 0.23$ & $4.76 \pm 0.19$ & $4.77 \pm 0.15$ \\
\hline TBA (mg malanoldehyde/kg) & $0.341^{\mathrm{a}} \pm 0.11$ & $0.361^{b} \pm 0.08$ & $0.379^{\circ} \pm 0.23$ & $0.411^{\mathrm{d}} \pm 0.33$ \\
\hline Total viable plate count (log cfu/g) & $2.41^{\mathrm{a}} \pm 0.93$ & $2.79^{b} \pm 0.71$ & $3.12^{\circ} \pm 0.49$ & $4.42^{d} \pm 0.33$ \\
\hline Yeast and mould count (log cfu/g) & - & - & $2.47 \pm 0.11$ & $2.54 \pm 0.51$ \\
\hline
\end{tabular}

Mean in row having different superscripts differ significantly $(p<0.01)$.

Table-3. Organoleptic qualities of spent chicken meat pickle during storage periods.

\begin{tabular}{lllc}
\hline dayAttribute & $\mathbf{0}$ day & $\mathbf{3 0}^{\text {th }}$ day & Storage days \\
\hline Colour & $6.67 \pm 0.25$ & $6.61 \pm 0.45$ & $\mathbf{6 0}^{\text {th }}$ day \\
Flavour & $6.84^{\mathrm{a}} \pm 0.54$ & $6.62^{\mathrm{a}} \pm 0.11$ & $6.59 \pm 0.32$ \\
Texture & $6.61 \pm 0.31$ & $6.54 \pm 0.54$ & $6.39^{\mathrm{b}} \pm 0.41$ \\
Juiciness & $6.91 \pm 0.24$ & $6.82 \pm 0.17$ & $6.58 \pm 0.78$ \\
Overall Acceptability & $6.79^{\mathrm{a}} \pm 0.22$ & $6.71^{\mathrm{a}} \pm 0.31$ & $6.74 \pm 0.44$ \\
\hline
\end{tabular}

Mean in row having different superscripts differ significantly $(p<0.01)$.

with occasional stirring for 3 minutes and allowed to cool at room temperature. The cooled meat pickle was then packed in pet jars and stored in a dry place at ambient temperature for studying the product's shelf life and other quality attributes.

Moisture, crude protein, fat and total ash content of the pickle were determined as perAOAC [5]. The $\mathrm{pH}$ value of the prepared pickle was determined by using a digital pH Meter (Systronics, Model 335) and by following the method as described by Pippen et al. [6] while the TBA value of the product was determined by using a Lomb and Bousch Spectrophotometer at 530 $\mathrm{nm}$ following the standard method as described by Witte et al. [7].

The Total viable plate count (TVPC) and yeast and mould counts of ready-to-eat pickles were determined following the method as described by Harrigan and McCancy [8] and the results were expressed as $\log$ cfu (colony forming unit) per $\mathrm{g}$ of meat. Standard plate count agar (Make: HiMedia, Code- M091) and Rose Bengal Chloramphenicol Agar (Make: HiMedia, Code- M640) were used for total viable plate count and yeast and moulds count respectively.

The sensory evaluation in respect of colour, flavour, texture, juiciness and overall acceptability was carried out by using a 7-point hedonic scale (7-like extremely, 1- dislike extremely) and by following the method as described by Malik et al. [9].
All the spent chicken meat pickles were evaluated for the above mentioned quality attributes at 30 days intervals and up to 90 days of storage at room temperature. A total of 5 batches of pickles were prepared and average of 3 replicates was recorded for each parameter except in the sensory evaluation. The data thus obtained were subjected to statistical analysis as per the method described by Snedecor and Cochran [10].

\section{Results and Discussion}

The ready-to-eat spent chicken meat pickle of spent chicken contained $61.89 \pm 0.12 \%$ moisture, 17.28 $\pm 0.56 \%$ crude protein, $14.65 \pm 0.16 \%$ ether extract and $3.35 \pm 0.17 \%$ total ash. The composition of the meat pickle was found to be in close agreement with the reports of Kumar and Tanwar [11] who studied the effect of clove powder in the preparation of nuggets from spent chicken.

The $\mathrm{pH}$ of spent chicken meat pickle ranged between $4.72 \pm 0.12$ to $4.77 \pm 0.15$ in the entire study period and its value did not differ significantly amongst the periods of storage. The results of the present study in respect of $\mathrm{pH}$ has further strengthened the reports Nayak et al. [1] and Das et al. [12] who also studied the $\mathrm{pH}$ of chicken meat pickle and goat meat pickle by storing it at room temperature. In respect of TBA values (mg malonaldehyde/ $\mathrm{kg}$ ) it was increased from $0.341 \pm 0.11$ to $0.411 \pm 0.33$ from 0 day to $90^{\text {th }}$ day of 
storage and recorded significant differences $(\mathrm{p}<0.01)$ amongst the storage periods. As in the present study, increased TBA values during storage period were also recorded by Nayak et al. [1] in chicken pickle and Maiti et al. [13] in tenderized chicken gizzard and goat meat pickle. However, non-significant differences in TBA values were reported by Kanagaraju and Subramanian [14] in spent duck meat pickle stored for different periods (up to $90^{\text {th }}$ day) at room temperature.

The TVPC of the pickle recorded at various periods of storage were found to differ significantly $(p<0.01)$. The initial mean TVPC was recorded to be $2.41 \pm 0.93 \mathrm{log} \mathrm{cfu} / \mathrm{g}$ which increased significantly to $4.42 \pm 0.33 \mathrm{log} \mathrm{cfu} / \mathrm{g}$ of pickle on $90^{\text {th }}$ day of storage. Nayak et al. [1] also recorded similar trends in TVPC of meat pickle stored for different storage periods, however, Kanagaraju and Subramanian [14] observed a non-significant increase in the TVPC of spent duck meat pickle. The meat pickle prepared was found to be free from yeast and moulds up to $30^{\text {th }}$ days of storage. However, growth of yeast and moulds were detected on $60^{\text {th }}$ day onwards and the counts recorded on $60^{\text {th }}$ and $90^{\text {th }}$ day did not differ significantly. The findings of the present study corroborated well with the reports of Kanagaraju and Subramanian [14] and Nayak et al. [1]. Based on the results obtained on studying the $\mathrm{pH}$, TBA value, TVPC and also the yeast and mould counts of the meat pickle, it could be said that the 'meat pickle' will remain shelf-stable up-to 90 days of storage at ambient temperature.

Taste panel studied revealed non-significant differences amongst the storage periods in respect of colour, texture, juiciness. This was in close agreement with the reports of Kanagaraju and Subramanian [14] and Khanna et al. [15] who also did not record significant differences in the panel scores amongst the storage periods. However, significant decrease $(p<0.01)$ in the flavour and overall acceptability scores was recorded along with the increased periods of storage. The significant decrease in the flavour scores on prolonged storage might be due to the corres-ponding increase in TBA values of the meat product. A decrease in flavour scores along with the progression of storage period was also reported by Sen and Karim [16] in rabbit meat pickle. The decreased in the overall acceptability scores of the spent chicken meat pickle might be a corollary to the progressive decrease in the mean colour, flavour, texture and juiciness scores. Similar findings were also recorded by Kanagaraju and Subramanian [14] and Das et al. [12].

\section{Conclusion}

Spent hen meat can be effectively utilized to prepare value added ready-to-eat meat pickle with superior sensory quality, high nutritive value and remains safe for consumption up to $90^{\text {th }}$ day of storage at ambient temperature.

\section{Author's contribution}

AD Planned and carried out the research work. DRN and $\mathrm{MH}$ analysed the data, drafted and revised the manuscript. SKL Tested the samples for different parameters. All authors read and approved the final manuscript.

\section{Acknowledgements}

The authors are thankful to the Dean, College of Veterinary Science, AAU, Khanapara for providing necessary facility to carry out the investigation.

\section{Competing interests}

Authors declares that they have no competing interest.

\section{References}

1. Nayak, N. K., Singh, P. K. and Nanavati, S. (2011) Quality Characteristics of Matured Chicken Pickle. Indian Vet. J., 88(1): 54-56.

2. Gadekar, Y. P., Kokane, R. D., Suradkar, U. S., Thomas, R., Das, A. K. and Anjaneyulu, A. S. R. (2010) Shelf stable me at pickles- a review. Int. Food Res. J., 17:221-227.

3. Staff, C. E. and Darrow, M. I. Poultry Science, 32, 145. Cited by: Sahoo, J. (1983) Influence of sex on meaty cut up parts of desi duck carcasses in Kashmir. Indian J. Meat Sci. Technol., 3(1): 87-91.

4. Deogade, A. H., Zanjad, P. N., Ambadkar, R. K. and Raziuddin, M. (2008) Formulation of Spices mixture for preparation of Chicken Curry. Vet. World, 1(1): 18-20.

5. A.O.A.C. (2007) Official Methods of analysis of the Association of Official Analytical Chemist, $18^{\text {th }}$ Edn., USDA, Washington, D.C.

6. Pippen, E. L., De Fremery, D., Lineweaver, H. and Hanson, H. L. (1965) Chicken broth flavour and pH. Poultry Sci., 44: 816.

7. Witte, V. G., Krause, G. F. and Barley, M. E. (1970) A new extraction method for 2-thiobarbituric acid value for pork and beef during storage. J. Food Sci., 35:582 -583.

8. Harrigan, W. F. and McCance, M. E. (1976) Laboratory Methods in Food and Dairy Microbiology. Acad. Press., London.

9. Malik, A. A., Aremu, A., Bayode, G. B. and Ibrahim, B. A. (2011) A nutritional and organoleptic assessment of the meat of the giant African land snail (Archachatina maginata swaison) compared to the meat of other livestock. Livestock Research for Rural Development. 23(3): Article \#60.

10. Snedecor, G. W. and Cochran, W. G. (1994) Statistical Methods, $1{ }^{\text {st }}$ Edn., East West Press Pvt. Ltd., New Delhi.

11. Kumar, D. and Tanwar, V. K. (2011) Utilization of clove powder as phytopreservative for chicken nuggets preparation. J. Stored Products and Postharvest Res., 2(1): 11-14.

12. Das, A K., Sharma, R. B. and Singh, N. P. (2007) Quality and Storage Stability of Low Acid Goat Meat Pickle. American J. Food Technol., 2(6): 550-554.

13. Maiti, A.K., Ahlawat, S.S. and N. Khanna. (2009) Studies on Development of Tenderized Chicken Gizzard and Goat Heart Pickles. Indian J. Anim. Res., 43 (4): 255-258.

14. Kanagaraju, P. and Subramanian, A. (2012) Preparation of Spent Duck Meat Pickle and its Storage Studies at Room Temperature. American J. Food Technol. 7(1): 29-33.

15. Khanna, N., Sharma, D. P., Ahlawat, S. S. and Sahoo, J. (2004) Shelf stable bone in meat pickle from spent hen. $J$. Food Sci. Technol., 41:445- 447.

16. Sen, A. R. and Karim, S. A. (2003) Storage stability of rabbit pickle at room temperature. J. Food Sci. Technol., 40:197200. 